\title{
ADOPTION OF ONLINE RESOURCES TO IMPROVE THE MARKETING PERFORMANCE OF SMES
}

\author{
Anuj Kumarl, Asif Ali Syed², Anoop Pandey33 \\ 1. Aligarh Muslim University (AMU), Aligarh, India \\ 2. Department of Business Administration, Aligarh Muslim University, India \\ 3. Hemvati Nandan Bahuguna Garhwal University, Uttrakhand, India
}

Correspondence: anujsmooth@gmail.com

\begin{abstract}
With the increase in the pace of globalization, SMEs are facing stiff competition from multinational firms. The entrepreneurs owning SMEs have fewer funds, but they need to improve the output of their organizations. Technology adoption can help owners of SMEs to match up with the pace of multinational firms because it can increase their reach and improve overall performance. In this paper, the authors will discuss whether online resource adoption (social media, e-commerce, technology 4.0) will enhance the marketing standard of small and medium enterprises or not. SMEs can achieve economies of scale because of the prominent usage of technology. The findings of this paper will help owners/managers of Indian SMEs to understand the use of online resources in improving marketing within a limited budget. COVID-19 has also pushed all the organizations towards the usage of technology. Either big or small organizations, none of them can ignore the use of technical sources for marketing in this digital era.
\end{abstract}

\section{KEYWORDS}

SMEs, Online tools, social media, Digital Marketing, E-commerce, Management

\section{INTRODUCTION}

As the pace of globalization is increasing, either it is a developed country or a developing country, the pressure is also growing. The government in all the countries is putting pressure on the companies to generate more revenue, sales and fulfill the goals of sustainable development. The focus of the government is not only on big multinational organizations, but it is also on SMEs. While looking for a creative solution, the governments are hopeful towards SMEs' progress. SMEs can be a game-changer, but they need some support. $[1,2]$ have argued that technology

adoption could be helpful for SMEs in overcoming all types of challenges. The COVID-19 has portrayed different kinds of challenges to SMEs, and technology can overcome all those challenges. SMEs with a better marketing effort can be a front runner in their contribution towards national growth. In this paper, the researchers will explore the effect on the marketing performance of SMEs with the adoption of different forms of technology, and there will be a discussion on other elements of digital marketing that can be helpful for SMEs. Marketing through social channels and 
technology is still in a nascent stage, especially in SMEs located in developing countries.

\section{KEY OBJECTIVES}

The key objective of this paper is mentioned below.

- The key objective is to derive the various benefits in the marketing performances of SMEs by adopting different forms of technology, i.e., social media tools, e-commerce, and ICT tools.

\section{PROBLEMS OF SMES}

The definition of SMEs is different as per continent and country, but these SMEs have been categorized based on investment and people employed. SMEs are critical contributors to economic growth in both developed and developing countries. On the one hand, the government is expecting SMEs to contribute towards success, while on the other hand, the government is not able to relocate the resources towards SMEs. The owners and managers of SMEs are working in the dearth of resources. SMEs are producing goods and services, and they need to tap a much broader market if they want to increase their output and contribution to the economy. No one can deny the fact that marketing plays a vital role in managing the relationship between customers and firms in the business.
SMEs must reach many customers, but they have limited finance. Traditional marketing sources are costly, and SMEs also need to show some innovation in their approach. Customers are essential for big as well as small organizations but reaching many customers is a challenge for SMEs. The marketing department is a crucial department for SMEs because it connects the organization with the customers. Large multinationals are putting particular emphasis on marketing function because they want to increase their market share and sales. SMEs also need to understand the importance of marketing function because this function ultimately increases the sales of the organization. Technology adoption in any form can help organizations in sustainable development and finding solutions to problems [2, 3]. It can also help the organizations in improving their post-COVID performances. Pre Covid and Post Covid, marketing is always a challenge for SMEs. The list of problems is growing for SMEs, and some of the issues are mentioned below.

- How to tap the vast customer base?

- How to increase the market share within limited resources?

- How to reduce the expenses on marketing?

- How to produce more output in less input?

- How to improve the market presence and brand exposure?

\section{LITERATURE REVIEW}

\begin{tabular}{|l|l|l|}
\hline S. NO. & AUTHOR (S) & $\begin{array}{l}\text { HOW IS TECHNOLOGY ADOPTION IMPACTFL FOR THE } \\
\text { MARKETING ACTIVITIES OF SMES? }\end{array}$ \\
\hline 1 & {$[4]$} & $\begin{array}{l}\text { Twitter and other social media tools provide benefits for different } \\
\text { types of business in terms of networking, improved relationships, and } \\
\text { the online branding of firms. Usage of Twitter plays a vital role in } \\
\text { electronic word-of-mouth marketing in SMEs. }\end{array}$ \\
\hline 2 & {$[5]$} & $\begin{array}{l}\text { In traditional sources, SMEs are investing more money in marketing. } \\
\text { ICT tools can help those SMEs in the reduction of extra costs and } \\
\text { advertising. It will speed up communication and can reduce the } \\
\text { transaction cost. The physical limitations can also be avoided with } \\
\text { the usage of ICT tools. }\end{array}$ \\
\hline 3 & {$[6]$} & $\begin{array}{l}\text { The usage of web-based marketing tools is in the initial stage in } \\
\text { Malaysian SMEs, but this usage is beneficial for them. Web-based } \\
\text { marketing can reduce the efforts of SMEs. The use of websites and } \\
\text { emails as tools of web-based marketing can extend the approach } \\
\text { and range of SMEs. }\end{array}$ \\
\hline
\end{tabular}




\begin{tabular}{|c|c|c|}
\hline 4 & [7] & $\begin{array}{l}\text { The authors have suggested the reasons to adopt social media } \\
\text { marketing. Social media marketing helps in reducing advertising } \\
\text { costs, provides an essential competitive advantage, helps in } \\
\text { reaching new customers and target market. } \\
\text { The benefits of using social media marketing are increasing brand } \\
\text { awareness about the products, valuable customer feedback, } \\
\text { customer support, and it also improves the participation level of the } \\
\text { customers. }\end{array}$ \\
\hline 5 & [8] & $\begin{array}{l}\text { E-commerce adoption improves the overall marketing of SMEs. It } \\
\text { establishes two-way communication, which enhances the sales and } \\
\text { marketing efforts. It helps in customizing customer service, which will } \\
\text { further increase the customer satisfaction level. }\end{array}$ \\
\hline 6 & [9] & $\begin{array}{l}\text { Marketing through social media tools is more helpful in increasing } \\
\text { brand popularity, building more awareness, attracting a new set of } \\
\text { customers, building loyalty, and increase the customer base. The } \\
\text { adoption of social media channels enhances the marketing } \\
\text { performance of SMEs. }\end{array}$ \\
\hline 7 & [10] & $\begin{array}{l}\text { The content was written on Facebook, and Twitter social networking } \\
\text { sites play an essential role in attracting customers. It improves the } \\
\text { communication process and overall interaction with the customers. }\end{array}$ \\
\hline 8 & {$\left[\begin{array}{lll}1 & 1\end{array}\right]$} & $\begin{array}{l}\text { Facebook usage positivelyimpacts the non-financial performance } \\
\text { of the firms as it is helpful in cost reduction in marketing. The } \\
\text { information flow is for a much wider audience, and it improves } \\
\text { customer relations as well. }\end{array}$ \\
\hline 9 & [12] & $\begin{array}{l}\text { E-Marketing through various technological channels is easy to use, } \\
\text { and it increases productivity as well. E-Marketing is suitable for } \\
\text { advertisement purposes and provides a better way to } \\
\text { communicate with customers. In fact, it helps in two-way } \\
\text { communication with the customers. }\end{array}$ \\
\hline 10 & [13] & $\begin{array}{l}\text { The authors argued that digital marketing helps SMEs in business } \\
\text { expansion, speedy communication, increasing sales, and creating } \\
\text { more business awareness. The essential tools for digital marketing } \\
\text { are SEO, SEM, emails, and other types of social media. } \\
\text { SMEs need to improve their knowledge of digital marketing to grasp } \\
\text { the full advantage of opportunities created by digital marketing. }\end{array}$ \\
\hline 11 & [14] & $\begin{array}{l}\text { Marketing through digital channels has some challenges, but it } \\
\text { offers SMEs an increased number of opportunities to innovate their } \\
\text { business performance, and it can also help in redefining customer } \\
\text { segments. }\end{array}$ \\
\hline 12 & [15] & $\begin{array}{l}\text { The findings of the research suggest that SMEs are moving towards } \\
\text { social media marketing due to low costs. The adoption of social } \\
\text { media marketing is helpful in improving product sales, and it will also } \\
\text { increase profits and customer satisfaction. }\end{array}$ \\
\hline 13 & [16] & $\begin{array}{l}\text { The E-marketing services with the usage of technology help in } \\
\text { improving the export performance of the firms. }\end{array}$ \\
\hline
\end{tabular}




\begin{tabular}{|c|c|c|}
\hline 14 & [17] & $\begin{array}{l}\text { E-commerce adoption is helpful for the marketing performance of } \\
\text { the organization as it increases sales and improves the company } \\
\text { image. }\end{array}$ \\
\hline 15 & [18] & $\begin{array}{l}\text { Social media marketing improves the overall competitiveness of } \\
\text { tourism SMEs in South Africa because it provides a chance to do } \\
\text { two-way communication with the customers. Marketing on social } \\
\text { media channels increases the market expansion. }\end{array}$ \\
\hline 16 & [19] & $\begin{array}{l}\text { The researchers have argued that social media tools play an } \\
\text { essential role in the business growth of SMEs in all the dimensions of } \\
\text { the marketing mix, business expansion, and customer relationship } \\
\text { management. }\end{array}$ \\
\hline 17 & [20] & $\begin{array}{l}\text { This study suggests that social media tools are not only helpful in } \\
\text { marketing, but they are also helpful for the sustainable } \\
\text { development of SMEs. }\end{array}$ \\
\hline 18 & [21] & $\begin{array}{l}\text { In this era of globalization, web } 2.0 \text { tools are used as integrated } \\
\text { marketing tools for the business expansion of SMEs. }\end{array}$ \\
\hline 19 & [22] & $\begin{array}{l}\text { The authors have argued and concluded that e-commerce } \\
\text { adoption has a positive effect on the sale performance of SMEs. It } \\
\text { increases the sales of SMEs and improves the relationship between } \\
\text { the SMEs. The usage of e-commerce adoption results in increasing } \\
\text { the income level of SMEs. As the income level of the SMEs will } \\
\text { increase, it helps in improving the growth of the same. }\end{array}$ \\
\hline 20 & [23] & $\begin{array}{l}\text { The adoption of e-commerce and technologies helps the } \\
\text { organizations in achieving more in terms of marketing in lesser time. }\end{array}$ \\
\hline 21 & [24] & $\begin{array}{l}\text { Digital marketing is making the work easy for SMEs because it will } \\
\text { help them in providing accurate and on-time information. Digital } \\
\text { marketing made the information flow more comfortable and } \\
\text { natural. There are specific barriers to adopting digital marketing } \\
\text { tools and their usage, but the process is helpful in increasing } \\
\text { awareness. }\end{array}$ \\
\hline 22 & [25] & $\begin{array}{l}\text { The authors have argued that digital marketing through social } \\
\text { media tools helps organizations in achieving sustainable growth. }\end{array}$ \\
\hline 23 & [26] & $\begin{array}{l}\text { The study reveals that if the organizations adopt information and } \\
\text { communication technology, it will help them in improving their sales } \\
\text { performance and take it to another level. The SMEs who are not } \\
\text { investing in information and communication technology will soon } \\
\text { be obsolete. }\end{array}$ \\
\hline
\end{tabular}

\section{IMPLICATIONS FROM THE LITERATURE REVIEW}

In the broader context, the literature review suggests that SMEs around the world have adopted mainly three types of technology, i.e., e-commerce websites, social media tools, and ICT tools. The SMEs are also moving towards technology 4.0, but it is in a very nascent stage [2]. [2] have argued about the adoption of different types of technology in which they have discussed technology 4.0 as an essential element, but the usage of that type of 
technology is not much. There are specific critical insights drawn from the literature review. The first insight from the literature review is that though SMEs have started using technology, there are more challenges in technology adoption. The employees working in SMEs need more training on technological tools for producing better results. There is no doubt in the fact that usage of technology reduces the expenses of SMEs to the desired level. The use of technology helps SMEs in achieving economies of scale, and it allows them to fulfill their goals.

In this paper, the main aim of the authors is to find out the effect of technology adoption on the marketing performance of SMEs. It can be evoked out that the marketing performance of the firms is improving with the usage of ICT tools, e-commerce, and social media tools. SMEs can expand their reach, and the technology is helping them in business expansion over the boundaries. SMEs can market their product well and be able to take their products/services to many customers. In this era of globalization, the market is full of opportunities. The usage of technology is making the SMEs eligible to explore all the options which were not possible otherwise. Within limited finance, SMEs are growing only because of better usage of social media tools, e-commerce tools, and several other technological tools. Another aspect drawn out from the literature review is that technology adoption is also helping SMEs in moving towards sustainable development through sustainable marketing efforts. The owners and managers of SMEs also have the pressure of sustainability, and their practices should suffice the purpose of sustainability. Technology provides that impetus to the owners and managers of SMEs that they can move towards sustainable business practices. Marketing through social media and ecommerce tools is also helpful in improving brand awareness and overall feedback about SMEs. Basically, technological tools provide a way out of two-way communication between the employees and the organization.

\section{DIGITAL MARKETING: BRINGS NEW OPPORTUNITIES FOR SMES}

In the coming time, SMEs need to invest more in digital marketing because digital marketing can lead them towards the pathway of success. Digital marketing can provide equal opportunities to all businesses, either big or small. SMEs have limited finance, and digital marketing can flourish them in that limited finance. It has been noticed that companies using social media tools are generating $78 \%$ more business in comparison to the companies not using such tools. In actuality, the various components of digital marketing help the SMEs in targeting the right audience to whom they want to sell their product and generate high revenue as well. At the initial level, the buyers need some time of push or influence. Digital marketing provides that necessary impetus, power, and push to SMEs. Every SME wants to grow, and they want to sell their products/services in the global market. They have the option to market their products/services through traditional marketing channels like print media or television advertisements. At the initial level, the SMEs want to reach many people, there may be few who will show interest in products/services, but they cannot limit their approach. The online marketing tools inculcated in digital marketing can provide maximum reach to SMEs, which traditional forms of marketing cannot do for them. Online marketing can interact with prospective customers, which conventional forms of marketing cannot do. Traditional marketing is one-way marketing as it does not provides an opportunity for the customers to revert to an advertisement in any paper. Customers see an ad in print media, magazines, newspapers, or television, but they cannot revert their opinion or feedbacks while the scenario is different in online or digital marketing. Primarily organizations using social media tools for digital marketing, and those social media tools provide an opportunity for two-way communication between the company and the customers. The organizations can save a lot of money and reach a global audience within no time. Digital marketing analytics can help them to track the responses of their efforts as well. SMEs do not have many investments. They have limited investments, and in those limited investments, they need to manage the overall return on assets [27, 28]. Social media tools and online marketing can boost the overall return on investments for marketers.

There is no doubt in the fact that online tools and technologies are helping SMEs in increasing their sales and widening their business horizon. There are more than 3.6 million internet users across the world, and digital tools can help companies in reaching those users. There are specific strategies that can help SMEs is improving their digital marketing efforts.

- The first and foremost thing more SMEs do is to inculcate SEO analyzer tools on their websites. SEO helps the users in finding your website. When users put specific phrases or words, SEO marketing helps 
them to find your website easily. SEO analyzer tool allows SMEs to find quality traffic. It is an inbound marketing process in which it is easy to reach out to the customers when they want your products and services [29]. Inbound marketing through SEO tools is much more customer-centric in which cold calling, cold emails, and interruptive advertisements can be avoided. Search engine optimization helps the organization in avoiding any unnecessary costs. The content published on the website matters, but once that content has been published, the organic traffic keeps coming on the website. SEO and PR are not different marketing strategies. One can use them in a combined manner. SEO marketing and PR marketing are other, but one can always use them in a combined way. Content is the key, but it connects both SEO and PR. SEO professionals can strengthen their PR with a substantial range. SEO strategy helps the organizations in moving ahead in the competition by solid content and blog marketing.

- The second marketing tactic for SMEs is to perform a keyword search. Keyword search through keyword planners can be beneficial for organizations. It opens new opportunities to rank your website high in competition against others [30]. The keyword planner on Google helps in finding new keywords and phrases. It helps in discovering different types of search volume trends and historical data. One can choose the keywords as per budget and bid prices. It is required to narrow down the result as per geographic location, date ranges, and other things. SMEs which are mainly introducing new products or services should find new keywords and check the volume and forecasts against those keywords. The average monthly searches and the work help the companies in identifying the potential benefits of the keywords.

- The third most crucial marketing tactic is to use blogging. WordPress can really be helpful for SMEs in writing a blog and all. Around the world, more than 409 million people read 23.7 billion blog posts [29]. The blog posts are an effective and interactive medium to connect with the customers. It provides opportunities to express ideas, emotions, and inner self.

- The fourth important marketing tactic which SMEs can use is the effective use of content marketing.
Content is the key to drive the customers. It is essential for marketers to create quality, reliable and valuable content because, ultimately, content goes that initial thrust in the customers. The marketers can explore different dimensions of content. For example, one can always try creativity and innovation in content marketing through videos, podcasts, and online courses. SMES can also take the help of outside content writers to prepare quality content.

- Email marketing is another important and decisive tool of digital marketing. Daily there is a lot of traffic on the websites. It is not mandatory that every person who is visiting the website will purchase the products or services, but marketers can capture the email address of the visitor. Later, emails remain as the highest converting channel for the leads generated. Email marketing is low in cost but has a global reach. It is easy to set up and automate email marketing. It is also the right way of interaction.

- Data analytics can be helpful for SMEs in their business growth because analytics can help you in understanding the demographics of your respondents or prospective customers. The main difference in traditional marketing is that the organizations are unaware of the future customers, but digital marketing and analytics will take you to the right customers. While doing traditional marketing, one never knows if he/she is targeting the right clientele or not. Digital marketing and analytics are much more economical and conventional in comparison to traditional media [31]. It is saving the cost of the company and improve their offerings because SMEs can track the seasonal changes in demand.

\section{KEY FINDINGS AND IMPLICATIONS FOR MANAGERS}

The key findings of this secondary research are mentioned below. The manager of the SMEs should seriously think about technology adoption because it can take marketing to another level. The managers should train their employees on the usage of online marketing tools because it is the need of the hour. The managers/owners of the organization should transfer the knowledge of technology usage to their employees. 
- The primary finding of this paper is the marketing efforts of SMEs improve with the adoption of technology because it helps the organization to reach prospective customers, which is not possible with traditional marketing.

- Secondly, marketing through different technologies also helps in saving the cost, time, and efforts of the company.

- Thirdly, digital marketing is the new dimension of the technology mix, which can help SMEs in increasing their sales and reducing their cost. The different components of digital marketing help the marketing in accessing the market needs ideally.

- The online marketing tools and marketing through social media channels will also help the organizations in achieving their goals of sustainability.

- The traditional marketing tools only offer one-way communication between customers and organizations, but marketing with the help of technology can encourage two-way communication between customers and organizations.

\section{CONCLUSION}

In the end, it can be concluded that technology adoption can be very fruitful for SMEs in improving the marketing and sales of products and services. As the number of internet users is increasing, the internet is the most prolific medium which connects customers with the company. SMEs have started using technologies, but still, the adoption is in a very nascent stage. COVID-19 pandemic introduced a push in technology, and in coming years, SMEs will be bent more towards digital marketing. Digital marketing offers several tangible and intangible benefits to SMEs, and SMEs should train themselves well to adopt the technology.

\section{References}

1. A. Kumar and N. Ayedee, "Sustainable development in SMEs through social media channels," International Journal of Management, Technology and Engineering, vol. 9, no. 6, pp. 1066-1075, 2019.

2. A. Kumar and N. Ayedee, "Technology Adoption: A Solution for SMEs to overcome problems during COVID-19," Academy of Marketing Studies Journal, vol. 25, no. 1, pp. 1-16, 2021.
3. A. Kumar, D. A. A. Syed and D. A. Pandey, "How Adoption of Online Resources Can Help Indian SMEs in Improving Performance during COVID-19 Pandemic," Test Engineering and Management, vol. 83, no. 83, pp. 3394-3400, 2020.

4. M. Bulearca and S. Bulearca, "Twitter: a Viable Marketing Tool for SMEs?," Global Business and Management Research: An International Journal, vol. 2, no. 4, pp. 296-309, 2010.

5. F. Nejadirani, M. Behravesh and R. Rasouli, "Developing Countries and Electronic Commerce the Case of SMEs," World Applied Sciences Journal, vol. 15, no. 5, pp. 756-764, 2011.

6. A. Omar, T. Ramayah, L. B. Lin, O. Mohamad and M. Marimuthu, "Determining Factors for the Usage of Web-Based Marketing Applications by Small and Medium Enterprises (SMEs) in Malaysia," Journal of Marketing Development and Competitiveness, vol. 5, no. 2, pp. 70-87, 2011.

7. I. Pentina and A. C. Koh, "Exploring social media marketing strategies in SMEs," Internatonal Journal of Internet Marketing and Advertising, vol. 7, no. 4, pp. 292-308, 2012.

8. M. A. Shouk, P. Megicks and W. M. Lim, "Perceived benefits and e-commerce adoption by SME travel agents in developing countries: Evidence from Egypt," Journal of Hospitality \& Tourism Research, vol. 37, no. 4, pp. 490-515, 2013.

9. M. I. Dahnil, K. M. Marzuki, J. Langgat and N. F. Fabeil, "Factors Influencing SMEs Adoption of Social Media Marketing," 2014.

10. D. Öztamur and I. S. Karakadılar, "Exploring the role of social media for SMEs: as a new marketing strategy tool for the firm performance perspective," Turkey, 2014.

11. S. Ainin, F. Parveen, S. Moghavvemi and N. I. Jaafar, "Factors influencing the use of social media by SMEs and its performance outcomes," Industrial Management \& Data, vol. 115, no. 3, pp. 570-588, 2015.

12. F. Iddris and M. Ibrahim, "Examining the relationships between e-Marketing adoption and Marketing Performance of Small and Medium Enterprises in," Journal of Marketing and Consumer Research, vol. 10, pp. 160-169, 2015.

13. H. Taiminen and H. Karjaluoto, "The usage of digital marketing channels in SMEs. Journal of Small Business 
and Enterprise Development," Journal of Small Business and Enterprise Development, vol. 22, no. 4, pp. 633-651,2015.

14. R. Jones, P. Alford and S. Wolfenden, "Entrepreneurial Marketing in the Digital Age: A study of the SME tourism industry," 2015. [Online]. Available: http://eprints.bournemouth.ac.uk/22932/1/Entrepre neurial\%20Marketing\%20in\%20the\%20Digital\%20Age \%20A\%20study\%20of\%20the\%20SME\%20tourism\%20in dustry.pdf. [Accessed 17 January 2021].

15. H. Musa, N. A. Rahim, F. R. Azmi, A. S. Shibghatullah and N. A. Othman, "Social Media Marketing and Online Small and Medium Enterprises Performance: Perspective of Malaysian Small and Medium Enterprises," International Review of Management and Marketing, vol. 6, pp. 1-5, 2016.

16. H. Erum, H. Rafique and A. Ali, "Effect of E-Marketing Adoption Strategy on Export Performance of SMEs," International Journal of Management Excellence, vol. 7, no. 2, pp. 1103-1110,2017.

17. R. Rahayu and J. Day, "E-commerce adoption by SMEs in developing countries: evidence from Indonesia," Eurasian Business Review, vol. 7, no. 1, pp. 25-41, 2017.

18. P. Rambe, "Social media marketing and business competitiveness: evidence from South African tourism SMMEs," Problems and Perspectives in Management, vol. 15, no. 2, pp. 411-423, 2017.

19. A. Kumar and N. Ayedee, "Social Media tools for business growth of SMEs," Journal of Management, vol. 5, no. 3, pp. 137-142, 2018.

20. A. Kumar and R. Aggarwal, "Sustainable development through social media tools," Journal of Management, vol.5, no. 5, pp. 47-51,2018.

21. A. Kumar and A. Pandey, "Usage of social media as an integrated marketing tool in business," Journal of Management, vol.5, no. 3, pp. 123-128, 2018.

22. A. Hendrawan, H. Sucahyowati and K. Cahyandi, "Ecommerce in small and medium enterprises (SMEs) in order to improve performance," Jurnal Terapan Manajemen dan Bisnis, vol. 4, no. 2, pp. 208-215, 2018.

23. D. D. T. Binh and N. X. Trung, "Research on the application of e-commerce to small and medium enterprises (SMEs): the case of India," International Journal of Economics and Management, vol. 1, no. 4, pp. 16-24, 2019.
24. M. T. Febriyantoro and D. Arisandi, "The Role of Digital Marketing in Improving Sales to SMEs in Dealing with ASEAN Economic Community," 2019.

25. S. Low, F. Ullah, S. Shirowzhan, S. M. E. Sepasgozar and C. L. Lee, "Smart Digital Marketing Capabilities for Sustainable Property Development: A Case of Malaysia," Sustainability, vol. 12, pp. 1-40, 2020.

26. I. Sunny R., E. Augustina and I. Otite Wisdom, "Technology adoption and sales performance of manufacturing small and medium enterprises in port harcourt," Journal of Marketing Development, vol. 5, no. 1, pp. 44-56, 2020.

27. Digital Marketing Institute, "Why Digital Marketing is Important for Small Business," 2020. [Online]. Available:

https://digitalmarketinginstitute.com/blog/whydigital-marketing-is-important-for-small-business. [Accessed 20 January 2021].

28. digitaldot, "Why is digital marketing so important for small businesses?," 2020. [Online]. Available: https://digitaldot.us/why-is-digital-marketing-soimportant-for-small-businesses/. [Accessed 20 January 2021].

29. N. Patel, "23 Amazing Online Marketing Tactics for Small Businesses With Low Budgets," 2020. [Online]. Available: https://neilpatel.com/blog/low-budgetonline-marketing-strategies/. [Accessed 21 January 2021].

30. buildfire, "16 Awesome Marketing Strategies For Small Businesses," 2020. [Online]. Available: https://buildfire.com/marketing-strategies-for-smallbusinesses/. [Accessed 21 January 2021].

31. Great Learning Team, "How Data Analytics Can Help in Small Business Growth," 2020. [Online]. Available: https://www.mygreatlearning.com/blog/dataanalytics-can-help-in-small-business-growth/. [Accessed 21 January 2021]. 